\title{
NEGARA KESATUAN
}

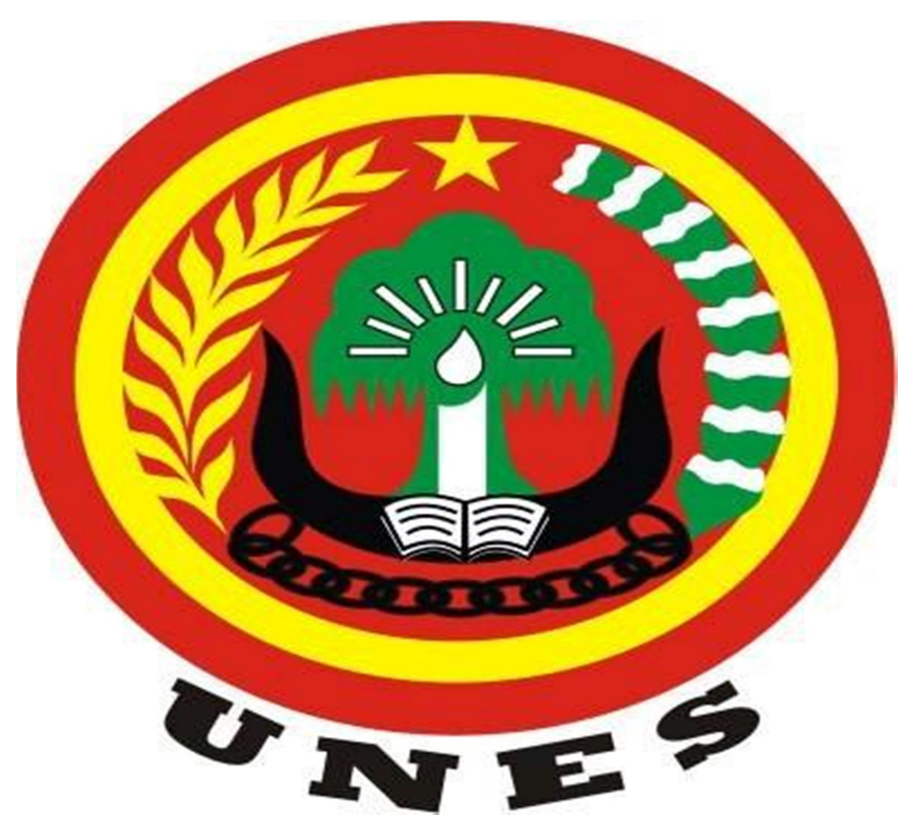

NAMA

NO BP

EMAIL

PERGURUAN TINGGI
: MEIDIAR GEA

: 2010003600095

: meidiargea@gmail. Com

: UNIVERSITAS EKA SAKTI PADANG 


\section{Pendahulua}

Negara kesatuan republik Indonesia (NKRI) merupakan negara yang di kenal sebagai nusantara yang artinya Negara kepulauan yang terdiri dari ribuan pulau yang terbentang dari sabang sampai merauke, dan didiami oleh ratusan juta penduduk. NKRI dikenal juga sebagai Negara yang memiliki keragaman budaya, ras, suku, dan agama yang berbeda-beda sehinga tercermin dalam satu ikatan " Bhineka tunggal ika " yang artinya "walaupun berbeda tetap satu jua ".

Indonesia mengalami beberapa kali pergantian bentuk Negara, mulai dari tanggal 6-15 desember 1949, terbentuklah republik Indonesia serikat (RIS), kemudan tanggal 27 desember 1949 Belanda men gikuti kedaulatan Indonesia berubah menjadi Negara serikat, bangsa Indonesia bertekad untuk mengubah RIS menjadi Negara kesatuan republik indonesia. Pada 17 agustus 1950 . RIS secara resmi dibubarkan dan indonesia kembali ke bentuk Negara kesatuan. tujuan NKRI adalah seprti tercantum dalam pembukaan UUD 1945 yaitu pada alinea ke 4 yang berbunyi "melindungi segenp bangsa Indonesia dan seluruh tumpah drah Indonesia, memajukan kesejahteraan umum mencerdaskan kehidupan bangsa, dan ikut serta melaksanakan keteriban dunia yang berdasarkan kemerdekaan, perdamaian abadi, dan keadilan sosial ".

Proklamasi kemerdekaan 17 agustus 1945, Indonesia menjadi Negara yang berdaulat dan berhak untuk mebntuk nasib dan tujuannya sendiri. Bentuk Negara yang dipilih oleh para pendiri bangsa adalah Negara kesatuan republik inonesia. Dalam perjalan sejarah ada upaya untuk menggantikan bentuk Negara, tetapi upaya itu tidak bertahan lama dan selalu digagalkan oleh rakyat. Higga sampai sekarang ini Negara kesatuan itu tetap dipertahankan. Kita sebagai generasi penerus wajib turut serta dalam usaha membela Negara, menjaga sikap, dan perilaku dalam mempertahankan NKRI.

Untuk mnegetahui pengertian NKRI, dan cara menjaga keutuhan NKRI, dalam makalah ini penulis akan mengulasnya kembali pada bab pembahasan selanjutnya. 


\section{PEMBAHASAN}

\section{A. Pengertian Negara kesatuan}

Arti Negara kesatuan adalah Negara yang berdaulat, diselenggarakan sebagai satu kesatuan tungggal, dimana perintah pusat merupakan yang tertinggi serta satuan - satuan subnasionalnya hanya menjalankan suatu kekuasaan yang sudah dipilih oleh pemerintah pusat untuk didelegasikan. Bagian pemerintahan kesatuan ini diterapkan oleh banyak Negara di dunia.

Dalam Negara kesatuan hanya ada satu konstitusi, satu kepala Negara, satu dewan menteri (kabinet), serta satu parlemen.

Demikian pula dengan pemerintah, yaitu pemerintah pusat yang memegang wewenang tertinggi di dalam segala aspek pemerintahan. Ciri utama Negara kesatuan adalah supremasi parlemen pusat dan tidak adanya badan -badan lain yang berdaulat.

\section{B.Macam-macam sistem Negara kesatuan}

Negara kesatuan di bedakan menjadi 2 macam yaitu:

\section{a. Negara kesatuan sistem sentralisasi}

Sistem sentralisasi adalah bentuk Negara dimana pemerintah pusat memiliki kedualatan penuh untuk menyelengarakan urusan pemerintah dari pusat hingga daerah termasuk segala hal yang menyangkut urusan pemerintahan daerah. Pemerintah daerah hanya bersifat pasif dan menjalankan perintah dari pemerintahan pusat. singkatnya pemerintah daerah hanya sebagai pelaksanaan belakang.

Contoh : Negara yang menerapkannya adalah jerman pada masa hitler

- Kebaikan Negara kesatuan sistem sentralisasi adalah :

Terdapat keseragaman hukum diseluruh wilayah Negara

Pemerintah mengurus langsung semua urusan sampai kedaerah

Tidak membtuhkan biaya besar

- kelemahan Negara kesatuan sistem sentralisai adalah :

Bertumpuknya pekerjaan pemerintah pusat yang dapat menghambat proses pelaksanaan pembangunan .

Rakyat akan bersifat apatis dan tidak mempunyai tanggung jawab dalam pelaksanaan pembangunan di daerahnya.

Pertuaran yang dibuat pemerintah pusat sering tidak sesuai dengan kebutuhan daerah 


\section{b. Negara kesatuan sistem desentralisasi}

Negara kesatuan sistem desentralisasi adalah bentuk Negara dimana pemerintah pusat sebagai pemegang kekuasaan tertinggi dalam Negara memberikan sebagian kekuasaanya kepada daerah untuk mengatur dan mengurus rumah tangganya sendiri di sebut hak otonom .

Dalam sistem pemerintahan ini daerah membuat peratuaran yang sesuai dengan kondisi daerahnya, asal peraturan itu tidak bertentangan dengan peraturan di atasnya. Pemerintah pusat tidak lagi memegang kekuasaan seluruh urusan pokok saja, seperti urusan pemerintahan umum, politik, keuangan dan hubungan luar negeri. Contoh Negara yang menrapkan sistem ini adalah Indonesia .

- Kebaikan dari Negara kesatuan - kesatuan dengan sistem desentralisasi adalah :

Pemrintah daerah dapat membuat peraturan yang sesuai dengan situasi dan kondisi daerahnya .

Karena peraturan sesuai dengan kondisi dan keadaan daerahnya maka rakyat dapat berperan secara aktif dalam pembangunan untuk memajukan daerahnya.

- Kelemahan Negara kesatuan dengan sistem desentralisasi adalah :

Tidak adanya keseragaman peraturan diseluruh wilayah Negara

Sistem ini membutuhkan biaya yang besar .

\section{Bentuk Negara kesatuan}

Bentuk Negara kesatuan merupakan bentuk Negara yang sederhana tetapi dapat menghasilkan Negara yang kuat karena hanya terdapat satu pemerintah yang berdaulat ke dalam dan keluar. Sisi negatifya dikhawartikan bentuk Negara ini menimbulkan pemusatan kekuasaan yang birokratis sehinga dapat menghambat kelancaran urusan pemerintahan. keburukana itu dapat dihilangkan apabila pelaksanaan kekuasaan Negara memiliki kontrol yang tinggi terhadap diri sendiri (moral) dan ada kontrol dari rakyat melalui lembaga yang berwenang .

Bentuk Negara kesatuan memiliki ciri- ciri sebagai berikut :

- Terdapat pemerintah pusat yang memilki kedaulatan baik kedalam maupun di luar .

- Terdapaat suatu undang - undang dasar yang berlaku untuk seluruh wilayah Negara.

- Terdapat satu kepala Negara atau pemerintahan .

- Terdapat satu badan perwakilan rakyat .

Sedangkan bentuk Negara serikat merupakan Negara yang terdiri dari bebrapa Negara bagian dengan satu pemerintah pusat yang memiliki kedaulatan namun tiap Negara bagian punya kedaulatan ke dalam untuk mengatur wilayah masing-masing . tiap Negara bagian punya UUD sendiri, kepala Negara, dan badan perwkilan. Kekuasaan pemerintah pusat menyangkut urusan luar negeri, pertahanan dan keamanan, keuangan, dan peradilan. 


\section{D. konsep Negara kesatuan}

Negara kita adalah negara kestuan republik Indonesia atau sering disingkat menjadi NKRI. Istilah negara kesatuan sudah tertanam dalam pola pikir kita selaku warga negara Indonesia.

Konsep negara kesatuan atau unitarisme yaitu negara tunggal (satu negara) yang monosentris (berpusat satu ). Dalam negara kesatuan hanya ada satu pemerintahan, satu kepala negara, satu badan legislatif yang berlaku seluruh wilayah negara. Hakikat negara kesatuan sesungguhnya adalah kedaulatan tidak terbagi-bagi baik keluar maupun kedalam dan kekuasaan pemerintah pusat tidak dibatasi.

Indonesia adalah negara kepulauan terbesar di dunia yang terdiri dari kurang lebih 17.000 pulau. Negra kesatuaan republik Indonesia (NKRI) merupakan negara merdeka dengan aneka corak keragaman dan warna-warna kebudayaan. NKRI adalah kesatuan wilayah dari sabang di Nangroe aceh Darussalam (NAD) sampai merauke di irian jaya (papua). Indonesia terdiri dari berbagai suku, bahasa, dan agama, yang berbeda.

Karena terdiri dari banyak pulau, suku bangsa maka Indonesia menggunakan bentuk negara kesatuan. Banyak ahli yang mendefiniskan tentang pengertian negara kesatuan menurut para ahli, di antaranya sebagai berikut.

\begin{tabular}{|l|l|l|}
\hline No & NAMA PAKAR & MAKNA NEGARA KESATUAN \\
\hline 1 & Moh kusmadi dan Hamaily Ibrahim & $\begin{array}{l}\text { Negara Indonesia atau makna negara kesatuan adalah } \\
\text { negara yang memiliki susunan yang hanya terdiri dari atas } \\
\text { satu negara saja dan dalam negara tersebut tidak ada } \\
\text { negara lain }\end{array}$ \\
\hline 2 & Abu Daud Busroh & $\begin{array}{l}\text { Negara kesatuan adalah suatu negara yang tidak tersusun } \\
\text { dari beberapa negara melainkan negara bersifat tunggal } \\
\text { dan tidak terdapat negara lainnya dalam suatu negara } \\
\text { tersebut }\end{array}$ \\
\hline 3 & C.F. Strong & $\begin{array}{l}\text { Negara kesatuan merupakan bentuk negara yang memiliki } \\
\text { kedaulatan tertinggi berada di tangan pemerintah pusat. }\end{array}$ \\
\hline
\end{tabular}

Persamaan dari ketiga pendapat diatas adalah sama-sama memiliki makna bahwa negara kesatuan hanya terdapat satu negara saja, dan dalam suatu negara kesatuan tidak ada negara lainnya. Dan menurut saya tidak ada perbedaan dari ketiga pendapat diatas.

Negara kesatuan adalah suatu yang diselenggarakan sebagai satu kesatuan tunggal, dimana pemerintah pusat adalah yang tertinggi dan satuan-satuan subnasionalnya hanya menjalankan kekuasan kekuasaan yang dipilih oleh pemerintah pusat untuk di delegasikan. Beberapa negara di dunia yang menggunakan bentuk negara kesatuan antara lain sebagai berikut : 


\begin{tabular}{|l|l|l|}
\hline no & Nama Negara & Nama Kepala Negara/kepala pemerintah \\
\hline & Afghanistan & $\begin{array}{l}\text { Presiden ashraf Ghani, kepala badan } \\
\text { eksekutif, Abdullah Abdullah. }\end{array}$ \\
\hline & Republik Rakyat Tiongkok & $\begin{array}{l}\text { Presiden xi jinping perdana menteri li } \\
\text { keqiang }\end{array}$ \\
\hline & Jepang & Kaisar Akihito, perdana menteri shinjo Abe \\
\hline Filipina & $\begin{array}{l}\text { Presiden beningno Aquino III wakil } \\
\text { presiden jejomar Binay }\end{array}$ \\
\hline & Korea Selatan & $\begin{array}{l}\text { Presiden park Geun-hyem, perdana } \\
\text { menteri hwang kyo-ahn }\end{array}$ \\
\hline
\end{tabular}

Secara umum bentuk negara kesatuan memiliki beberapa keunggulan sebagai berikut:

1. Negara kesatuan secara structural lebih sederhana dengan bentuk federal.

2. Apa bila terdapat kekurangan tenga ahli dalam bidang pemerintahan maka kekurangan tenaga ahli tersebut dapat disiapkan oleh pemerintah pusat .

3. Relatif lebih stabil untuk mengurangi kecemburuan kemajuan antar daerah, karena bagi daerah yang kurang maju dapat dimintakan anggaran dari pusat dan subsidi-subsidi lainnya.

4. Mengurangi timbulnya sikap separatisme karena pemerintahan tetap dikendalikan dari pusat.

Secara umum bentuk negara kesatuan memiliki ciri-ciri sebagai berikut :

- Kedaulatan negara mencangkup ke dalam dan keluar yang ditangani oleh pemerintah pusat

- Negara hanya memiliki suatu UUD, satu kepala negara dan satu dewan perwakilan rakyat.

- Hanya ada satu kebijaksanaan yang menyangkut persoalan politik, ekonomi, social budaya serta pertahanan dan keamanan 


\section{PENUTUP}

Dari pengertian tersebut dapat di simpulkan, negara kesatuan merupakan negara yang pemerintah pusatnya mempunyai wewenang untuk mengatur keseluruhan daerah

Pemerintah pusat menguasai kedaulatan secara penuh baik ke dalam ataupun keluar dimana hubungan antara pemerintahan daerah dan rakyat nya dapat dilakukan secara langsung. Dalam negara kesatuan, hanya terdapat satu kepala negara, satu konstitusi, satu cabinet menteri, dan satu parlemen. Termasuk juga dengan pemerintahan, yaitu pemerintah pusat sebagai penguasa tertinggi dalam segala aspek pemerintahan.

Negara kesatuan memiliki dua sistem, yaitu sentralisasi dan desentralisasi. Dalam sentralisasi, artinya semua aspek diatur langsung oleh pemerintah pusat tanpa adanya campur tangan dari pemerintah daerah. Pemerintah daerah hanya berhak untuk menjalankan peraturan pemerintah pusat dan tidak berhak untuk mengatur rumah tangganya sendiri atau membuat peraturan sendiri.

Sementara itu desentralisasi bisa diartikan sebaliknya. daerah diberi wewenang untuk mengatur dan mengembangkan rumah tangganya secara mandiri (otonmi daerah), namun pemerintah pusat tetap berperan sebagai pemegang kekuasaan tertinggi. 


\section{DAFTAR PUSTAKA}

Laurensius Arliman S, Participation Non-Governmental Organization In Protecting Child Rights In The Area Of Social Conflict, The 1st Ushuluddin and Islamic Thought International Conference (Usicon), Volume 1, 2017.

Laurensius Arliman S, Partisipasi Masyarakat Dalam Pembentukan PerundangUndangan Untuk Mewujudkan Negara Kesejahteraan Indonesia, Jurnal Politik Pemerintahan Dharma Praja, Volume 10, Nomor 1, 2017, https://doi.org/10.33701/jppdp.v10i1.379.

Laurensius Arliman S, Peran Komisi Perlindungan Anak Indonesia Untuk Mewujudkan Perlindungan Anak, Jurnal Respublica Volume 17, Nomor 2, 2018.

Laurensius Arliman S, Menjerat Pelaku Penyuruh Pengrusakan Barang Milik Orang Lain Dengan Mempertimbangkan Asas Fungsi Sosial, Jurnal Gagasan Hukum, Volume 1, Nomor 1, 2019.

Laurensius Arliman S, Ilmu Perundang-Undangan Yang Baik Untuk Negara Indonesia, Deepublish, Yogyakarta, 2019.

Laurensius Arliman S, Isdal Veri, Gustiwarni, Elfitrayenti, Ade Sakurawati, Yasri, Pengaruh Karakteristik Individu, Perlindungan Hak Perempuan Terhadap Kualitas Pelayanan Komnas Perempuan Dengan Kompetensi Sumber Daya Manusia Sebagai Variabel Mediasi, Jurnal Menara Ekonomi: Penelitian dan Kajian Ilmiah Bidang Ekonomi, Volume 6, Nomor 2, 2020.

Laurensius Arliman S, Pendidikan Kewarganegaraan, Deepublish, Yogyakarta, 2020.

Laurensius Arliman S, Makna Keuangan Negara Dalam Pasal Pasal 23 E Undang-Undang Dasar 1945, Jurnal Lex Librum, Volume 6, Nomor 2 Juni 2020, http://dx.doi.org/10.46839/lliih.v6i2.151.

Laurensius Arliman S, Kedudukan Lembaga Negara Independen Di Indonesia Untuk Mencapai Tujuan Negara Hukum, Kertha Semaya Journal Ilmu Hukum, Volume 8, Nomor 7, 2020.

Laurensius Arliman S, Pelaksanaan Assesment Oleh Polres Kepulauan Mentawai Sebagai Bentuk Pelaksanaan Rehabilitasi Bagi Pecandu Dan Korban Penyalahgunaan Narkotika, Jurnal Muhakkamah, Volume 5, Nomor 1, 2020.

Laurensius Arliman S, Aswandi Aswandi, Firgi Nurdiansyah, Laxmy Defilah, Nova Sari Yudistia, Ni Putu Eka, Viona Putri, Zakia Zakia, Ernita Arief, Prinsip, Mekanisme Dan Bentuk Pelayanan Informasi Kepada Publik Oleh Direktorat Jenderal Pajak, Volume 17, No Nomor, 2020.

Larensius Arliman S, Koordinasi PT. Pegadaian (Persero) Dengan Direktorat Reserse Narkoba Polda Sumbar Dalam Penimbangan Barang Bukti Penyalahgunaan Narkotika, UIR Law Review, Volume 4, Nomor 2, 2020, https://doi.org/10.25299/uirlrev.2020.vol4(1).3779.

Laurensius Arliman S, Tantangan Pendidikan Kewarganegaraan Pada Revolusi 4.0, Ensiklopedia Sosial Review, Volume 2, Nomor 3, 2020.

Muhammad Afif dan Laurensius Arliman S, Protection Of Children's Rights Of The Islamic And Constitutional Law Perspective Of The Republic Of Indonesia, Proceeding: Internasional Conference On Humanity, Law And Sharia (Ichlash), Volume 1, Nomor 2, 2020.

Otong Rosadi danLaurensius Arliman S, Urgensi Pengaturan Badan Pembinaan Idelogi Pancasila Berdasarkan Undang-Undang Sebagai State Auxiliary Bodies yang Merawat Pancasila dalam Perspektif Hak Asasi Manusia, Prosiding Konferensi Nasional Hak Asasi Manusia, Kebudayaan dan Tujuan Pembangunan Berkelanjutan Indonesia pada Masa Pandemi Covid-19: Tantangan untuk Keilmuan Hukum dan Sosial Volume 1, Universitas Pancasila, Jakarta, 2020. 